\title{
SPATIAL ECOLOGY OF FEMALE MULE DEER IN AN AREA PROPOSED FOR WIND ENERGY DEVELOPMENT
}

\author{
Stephen L. Webb ${ }^{1,2,3}$, Matthew R. Dzialak' ${ }^{1}$ Dean Houchen ${ }^{1}$, Karl L. Kosciuch ${ }^{4}$, \\ and Jeffrey B. Winstead ${ }^{1}$
}

\begin{abstract}
Development for wind energy is increasing rapidly across the United States, particularly in Wyoming, despite a general lack of information on the potential interaction development could have on wildlife species. Therefore, knowledge of the space use and movement patterns of individuals can help define spatial distributions and management unit boundaries for populations prior to development. Such knowledge can also be used as baseline data from which to assess any future impacts on animal populations. We investigated the spatial ecology of female mule deer (Odocoileus hemionus; $n=18$ ) equipped with global positioning system collars from 23 February 2011 to 15 January 2012 in an area along the Wyoming-Colorado border that has been proposed for wind energy development. The objectives of this study were to collect predevelopment baseline estimates of annual and seasonal home-range and core area size and fidelity, movement between seasonal ranges, changes in the use of elevation, and movement patterns at 2 temporal resolutions (i.e., within-season diel patterns and year-round diurnal and nocturnal movements by week). Annual size of home ranges averaged 2495 ha $(\mathrm{SE}=121)$, whereas size of core areas averaged 310 ha $(\mathrm{SE}=30)$. Seasonal site fidelity was substantial $(81.1 \%, \mathrm{SE}=5.7)$ between successive cool-season ranges. Migration distances between cool- and warm-season home ranges were minimal (spring migration $=1319 \mathrm{~m}$; autumn migration $=1342 \mathrm{~m}$ ). Deer exhibited crepuscular movement patterns (peaks near 06:00 and 18:00) during the warm season but showed a diurnal movement pattern during the cool season (peak from 06:00 to 15:00). Partuition influenced movement during the warm season; movement was much reduced during a period from mid-June to mid-July. Deer in this population appear to be year-round residents that exhibit strong seasonal and annual fidelity to previously established ranges and modify movement patterns in relation to general changes in environmental conditions (e.g., snow). These findings can be used to define seasonally important ranges and formulate boundaries and sizes of game management units. Understanding fine-scale temporal movement allows the development of strategies that could minimize disturbance to deer while allowing for development or recreation.
\end{abstract}

RESUMEN.—El desarrollo de la energía eólica está creciendo con rapidez en los Estados Unidos, particularmente en Wyoming, a pesar de que no hay mucha información sobre la influencia que este desarrollo podría tener sobre las especies de vida silvestre. Por lo tanto, el conocer el uso del espacio y los patrones de movimiento de los individuos, puede ayudar a definir la distribución espacial y los límites de las áreas de las poblaciones antes del desarrollo, y servirán como información de referencia para evaluar el futuro impacto sobre las poblaciones animales. Investigamos la ecología espacial del venado bura (Odocoileus hemionus; $n=18$ ) con un sistema de rastreo de posicionamiento global, desde el 23 de febrero del 2011 hasta el 15 de enero del 2012 en un área de la frontera de Wyoming-Colorado que se sugirió como candidata para desarrollar energía eólica. Los objetivos de este estudio fueron obtener estimaciones de referencia previas al desarrollo, de tamaño y fidelidad del ámbito hogareño y del área central anual y estacional, el movimiento en las distintas áreas por estación, los cambios en el uso de la elevación y los patrones de movimiento en dos resoluciones temporales (es decir, patrones diarios dentro de la misma estación y movimientos diurnos y nocturnos de cada semana durante todo el año). El tamaño anual del ámbito hogareño tuvo un promedio de 2495 ha $(\mathrm{SE}=121)$ y el tamaño de las áreas centrales tuvo un promedio de 310 ha $(\mathrm{SE}=30)$. La fidelidad al lugar según la estación fue significativa $(81.1 \%, \mathrm{SE}=5.7)$ entre las áreas durante las estaciones de clima fresco. Las distancias de migración entre los ámbitos hogareños en las estaciones cálidas fueron mínimas (migración en primavera $=1319 \mathrm{~m}$; migración en otoño $=$ $1342 \mathrm{~m}$ ). El venado exhibió patrones de movimiento crepuscular (con puntos máximos entre 6:00 y 18:00 hrs.) durante la estación cálida, pero exhibió un patrón de movimiento diurno durante la estación de clima fresco (con puntos máximos entre 6:00 y 15:00 hrs.). El alumbramiento tuvo una influencia adicional en el movimiento; se redujo de manera significativa entre mediados de junio y mediados de julio. Esta población de venado parece ser residente permanente y mostró una gran fidelidad estacional y anual en áreas ya establecidas, y modificó sus patrones de movimiento en relación con los cambios generales de las condiciones ambientales (por ejemplo, la nieve). Estos hallazgos se pueden utilizar para definir áreas importantes según la estación y para establecer los límites y los tamaños de las áreas de caza. El comprender el movimiento temporal en detalle permite desarrollar estrategias para no alterar la vida del venado bura y al mismo tiempo permitir el desarrollo y el esparcimiento.

\footnotetext{
${ }^{1}$ Hayden-Wing Associates, LLC, 2308 South 8th St., Laramie, WY 82070

2E-mail: slwebb@noble.org

${ }^{3}$ Present address: Department of Computing Services, The Samuel Roberts Noble Foundation, 2510 Sam Noble Parkway, Ardmore, OK 73401.

${ }^{4}$ Tetra Tech EC, Inc., 1750 Southwest Harbor Way, Portland, OR 97201.
} 
Mule deer (Odocoileus hemionus) are an iconic and high-priority management species in Wyoming and throughout the Intermountain West because of their economic importance (Lutz et al. 2011). Of particular interest to managing agencies is the interaction between mule deer and human activity, especially when it occurs on crucial ranges (e.g., crucial winter range). Crucial range functions disproportionately in the persistence of mule deer populations relative to the range's spatial extent or frequency of use, because the range buffers populations against conditions (e.g., extreme weather, disturbance, or development) that could limit resource availability throughout the landscape. An area of crucial winter range for mule deer is located within the perimeter of our study area, which is proposed for development of wind energy. The proposed development area will include wind turbines and associated access roads and electrical collection lines. Regardless of whether development occurs in designated crucial range, development could influence populations during other critical seasons such as parturition.

The larger goal of this work is to provide baseline, or predevelopment, data that can be applied as part of infrastructure siting decisions (i.e., timing and spatial location) in the interest of balancing future wind energy development with conservation of land area and resources necessary for long-term persistence of mule deer populations. However, for many studies, data are collected during or after a treatment (e.g., development, catastrophic environmental event, etc.) has occurred. Consequently, inferences about the treatment are difficult to make because spatial and temporal controls are not available and animals are already exposed to some level of the treatment. Animals that have already been subjected to a treatment (e.g., development) may not exhibit innate behavioral patterns (Harju et al. 2011). Therefore, during conservation planning or siting of infrastructure, using information from animals whose behavior has not been modified may offer greater prioritization of crucial areas and landscape features in need of protection.

Many populations of mule deer are migratory (Watkins et al. 2007, Cox et al. 2009, Monteith et al. 2011); however, some populations do not undertake seasonal movements. For populations that do not migrate, the avail- ability of space and resources may be more important to resident herds because these herds do not have alternate behavioral strategies that allow them to exploit resources between disjunct seasonal ranges (Fryxell and Sinclair 1988). The most common form of migration in ungulates is one that follows an elevational gradient from higher-elevation summer range to lower-elevation winter range and most often coincides with availability of forage resources (Monteith et al. 2011). Therefore, the temporal aspects of elevational range use are important for minimizing disturbance to animals along these treks. Also coupled within these elevational treks is a finer temporalscale behavior that relates to diel movement patterns. Most temperate ungulates have a crepuscular activity and movement pattern (Eberhardt et al. 1984, Beier and McCullough 1990, Ager et al. 2003); thus, knowing times of greatest activity during critical seasons can help to minimize conflict between animals and human activity or disturbance. Within our study area, an area of crucial winter range exists, but because this mule deer population has not been studied on a year-round basis, it is unknown whether the animals are resident. Resident, year-round populations would use the same range for other critical seasons, which condition may require additional conservation intervention to protect animals during sensitive seasons such as parturition (Dzialak et al. 2011).

The specific objectives of this study were to estimate (1) annual and seasonal home-range and core area size and fidelity, (2) movement between seasonal ranges, (3) changes in the use of elevation, (4) diel movement patterns within season, and (5) weekly diurnal and nocturnal movements across an annual cycle. Additionally, these data can be leveraged to delineate game management units (GMUs) based on animal distribution and space use for the purpose of managing distinct herds or populations whose seasonal ranges occur within the GMU (Matthews and Coggins 1997). In the western United States, the designation of GMUs is a common practice for managing big game species, but little guidance is offered on how to set the extent of unit boundaries. Most GMUs were delineated in the 1950s and 1960s and aligned to legal or political boundaries (Brown 1992), all before the advent of sophisticated tools such as geographic information 
systems (GIS) and global positioning system (GPS) units that provide detailed information on the distribution of species.

\section{Methods}

\section{Study Area}

The study area ( 9248 ha) was located in southeastern Wyoming, situated along the Wyoming-Colorado border. Most land (81\%) was under private ownership (7504 ha) and, to a lesser extent, state (907 ha) or federal management (Bureau of Land Management; $837 \mathrm{ha}$ ). No paved road occurred within the study area, only improved (heavy equipment used to maintain natural or exotic material on road surface) and unimproved roads (heavy equipment not used to maintain roads). The study area was used primarily as second home getaways that were occupied minimally during winter, with the exception of one large private landholding that used the rangeland for grazing cattle. However, a portion of the study area has been proposed for the development of wind energy.

Topography was variable, ranging from flat to gently sloping grasslands, deep riparian gullies, and steep rock outcrops. Elevation ranged from 2100 to $3100 \mathrm{~m}$ and slope from $0^{\circ}$ to $52^{\circ}$. Five broad classes of vegetation/ landscape features occurred throughout the study area: grassland, shrubland, riparian, forest, and rock outcrop (Webb et al. 2013). Predominant plant species included mountain big sagebrush (Artemisia tridentata vaseyana), antelope bitterbrush (Purshia tridentata), alderleaf mountain mahogany (Cercocarpus montanus), skunkbush sumac (Rhus trilobata), Saskatoon serviceberry (Amelanchier alnifolia), quaking aspen (Populus tremuloides), willow (Salix spp.), rabbitbrush (Chrysothamnus spp.), alder (Alnus spp.), narrowleaf cottonwood (Populus angustifolia), and lodgepole pine (Pinus contorta). Average (1948-2010) minimum January temperature was $-12.7^{\circ} \mathrm{C}$, average maximum July temperature was $26.8^{\circ} \mathrm{C}$, and average annual snowfall was $123.2 \mathrm{~cm}$ (http://www.wrcc.dri .edu/; cited 28 September 2011).

\section{Capture and Handling}

We captured and fitted adult $(\geq 2.5$ years old), female mule deer $(n=19)$ with GPS collars programmed to collect 1 relocation every $3 \mathrm{~h}$ to allow estimation of diel and seasonal movement and space-use patterns that would help identify seasonal ranges, migration patterns, and interchange between GMUs. Deer were captured on 21-22 February 2011 by using helicopter and net-gun capture methods because these techniques are safe for a wide range of ungulate species with low direct and post-capture mortality (Webb et al. 2008). We manually restrained the legs of the deer and fitted deer with blindfolds to reduce stress. A single measurer aged deer according to tooth replacement and wear (Robinette et al. 1957), collected blood for tests of pregnancy-specific protein B (BioTracking, LLC, Moscow, ID), and measured morphometric traits and body condition score. Body scores near 1 for each of the estimation sites (i.e., shoulders, ribs, and hips) indicate that an animal is in poor or emaciated condition, whereas scores near 5 indicate that an animal is in very good condition (Riney 1960, Gerhart et al. 1996, Audigé et al. 1998). However, this method can be limited under some circumstances due to subjectivity (Cook et al. 2010). Last, we affixed uniquely numbered tags in each ear and fitted each deer with a GPS collar (TGW-4583, Telonics, Inc., Mesa, AZ) equipped with Argos satellite uplink capabilities (www.argos-system.org), which transmitted data every 7 days. All capture, handling, and marking procedures followed guidelines approved by the American Society of Mammalogists (Sikes et al. 2011) and the Wyoming Game and Fish Department (Chapter 33 Permit \#33-796).

\section{Home-Range Metrics}

Data were downloaded from collars and brought into a GIS to calculate movement distance and sizes of core areas and home ranges. We calculated annual and seasonal size of $50 \%$ core areas and 95\% home ranges by using adaptive-kernel estimators (Worton 1989) in Home Range Tools (Rodgers et al. 2005) for ArcGIS ${ }^{\circledR}\left(\right.$ Esri $^{\circledR}{ }^{\circledR}$, Redlands, CA). Annual core areas and home ranges were calculated for the period 23 February 2011-15 January 2012. We defined 2 seasons: (1) cool season, consisting of 2 disjunct sets of dates (23 February 2011-30 April 2011 and 1 November 2011-15 January 2012) and (2) warm season (1 May 2011-31 October 2011). We used unit-variance standardizations and the biased cross validation smoothing parameter when calculating volume-probability polygons. 
Other methods, such as utilization distributions (UD) and volume of intersection (VI), are available to assess site fidelity and intensity of use of areas in common (Millspaugh et al. 2004, Fieberg and Kochanny 2005). These metrics are particularly useful when temporal patterns of space use are warranted, because UD and VI account for nonuniform use of home ranges that occurs through time. However, our primary goal was to assess return of an individual to a general spatial domain used in a previous season; we were not interested in calculating intensity of use of areas in common among seasonal ranges. To assess coolseason fidelity of home ranges, we calculated overlap in 2-dimensional home ranges, and we report this as percentage of overlap. Overlap area of 2 successive cool-season home ranges was calculated, then divided by the size of the year-1 cool-season home range and multiplied by 100 to determine percentage of overlap. Next, we calculated arithmetic centroids of season-specific locations as another measure of site fidelity and an estimate of migration distance between seasonal ranges. The distance between centroids from season to season partially accounts for nonuniform use within the home range, whereby the arithmetic center of locations is weighted more heavily by temporal clusters of locations. After estimating centroids, we calculated the Euclidean distance between cool-season home ranges and the warm-season home range, and between the 2 cool-season home ranges (see above for dates).

\section{Movement Metrics}

Calculating empirical use of elevation (versus modeling the probability of elevation use in resource selection studies) over the course of an annual cycle provides detailed information on where mule deer are distributed — a key component in setting timing restrictions and development in areas used by deer. Therefore, we calculated the average elevational use by day after controlling for individual deer. These estimates were used to describe seasonal range-use patterns in conjunction with movement and homerange size; elevation also was considered in a more detailed resource selection study (Webb et al. 2013). We used a 10-m digital elevation model (DEM) reclassified to 30-m resolution. The raster values for the DEM were extracted to each deer location and then summarized using SAS ${ }^{\circledR} 9.2$ (SAS Institute, Inc., Cary, NC).
Movement distance was calculated as the Euclidean distance between successive locations for each individual deer. We analyzed movement metrics at the scale of the daily cycle (within-season; see above). Within-day movement distance was estimated across eight 3-h time blocks (00:00-03:00, 03:00-06:00, 06:00-09:00, 09:00-12:00, 12:00-15:00, 15:00$18: 00,18: 00-21: 00$, and 21:00-00:00). When reporting average 3 -h movement distance, we accounted for variation among individuals by (1) calculating average 3-h movements for each individual and (2) averaging 3-h movement distances across individuals. Thus, standard errors reflect variation in movement distance among individuals.

We further partitioned data to examine movement processes occurring at a finer temporal scale than season. To identify movement behavior that drives seasonal processes, we estimated average distance traveled during diurnal and nocturnal periods (week-specific to account for variation in sunrise and sunset) for each week during the course of the study. For each deer, distance traveled during each period was totaled for each day, and then the period-specific totals were divided by 7 to represent average daily distance traveled by week for each respective period. The sampling unit was an individual deer, so standard errors represent variation among individuals. We used SAS ${ }^{\circledR} 9.3$ for all movement analyses (i.e., descriptive statistics).

\section{Results}

We captured 19 female mule deer but analyzed data for 18 individuals because one female was struck by a vehicle $<30$ days after collaring. All other deer survived the entire study period (apparent annual survival 94.7\%). Females ranged in age from 2.5 to 8.5 years $(\bar{x}$ $=4.8$ years, $\mathrm{SD}=1.5)$. Blood tests revealed that all deer were pregnant, and body condition scores indicated deer were healthy at time of capture during late winter (22-23 February 2011). Average body condition scores were 3.4 (range 3-4), 3.5 (range 2-4), and 3.5 (range 3-4) for the shoulder, rib, and hip regions, respectively.

\section{Home-Range Metrics}

Annual home ranges and core areas were estimated based on an average of 2590 locations 


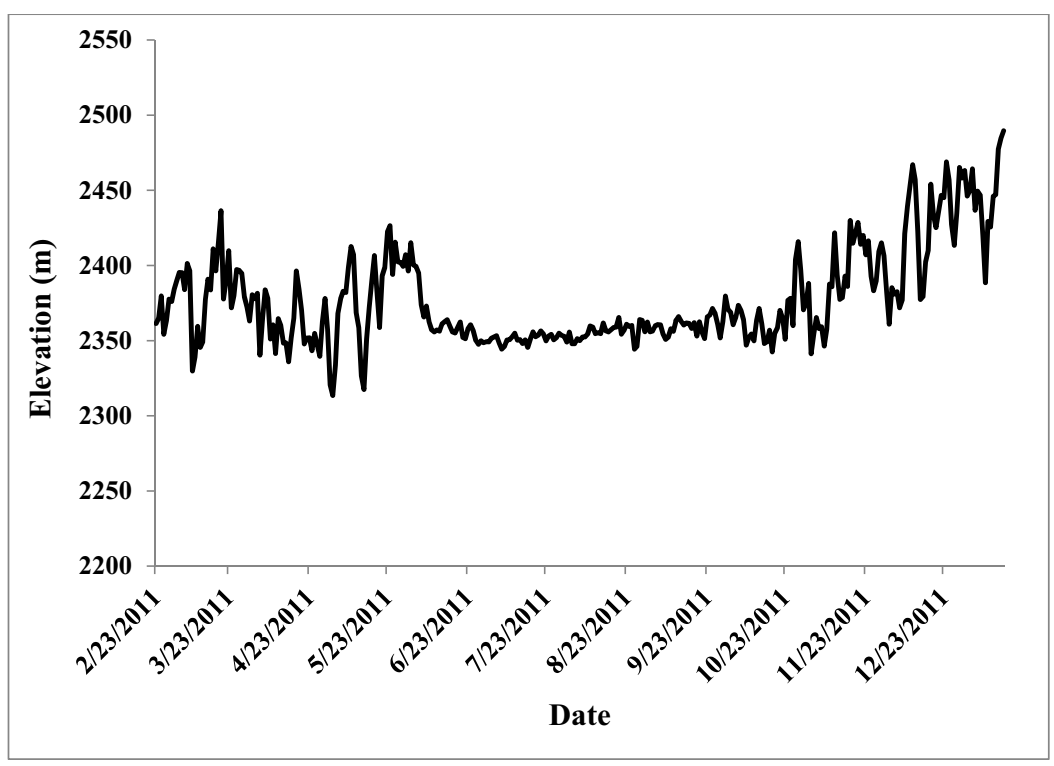

Fig. 1. Mean daily elevation (m) used by female mule deer (Odocoileus hemionus) from 23 February 2011 to 15 January 2012 in southern Wyoming and northern Colorado.

$(\mathrm{SD}=14$, range 2565-2606). Size of home ranges averaged 2495 ha $(\mathrm{SE}=121$, range 1681-3235 ha), whereas size of core areas averaged 310 ha $(\mathrm{SE}=30$, range $65-531 \mathrm{ha})$. When estimating warm-season ranges, we used an average of 1456 locations $(\mathrm{SD}=13$, range 1429-1470). Average sizes of home ranges and core areas during the warm season were 1592 ha $(\mathrm{SE}=201$, range 678-3109 ha) and 137 ha ( $\mathrm{SE}=20$, range 50-326 ha), respectively.

We estimated cool-season ranges for 2 disjunct seasons. We used an average of 535 locations $(\mathrm{SD}=1$, range 534-536) during year 1 and 600 locations (SD $=3$, range 592-601) during year 2. Home-range size averaged 2411 ha ( $\mathrm{SE}=258$, range 1471-6104 ha) and 2923 ha $(\mathrm{SE}=252$, range 1334-4323 ha) during years 1 and 2, respectively. Average sizes of core areas during year 1 and 2 were 465 ha $(\mathrm{SE}=$ 49, range 274-1062 ha) and $543 \mathrm{ha}(\mathrm{SE}=65$, range 157-846 ha), respectively. We used the percentage of overlap between 2 successive cool-season home ranges as a measure of site fidelity. On average, the year- 2 cool-season home range overlapped $81.1 \%$ of the year-1 cool-season home range $(\mathrm{SE}=5.7$, range $25 \%$ $100 \%)$.

As another measure of site fidelity and seasonal migration distance, we calculated the pairwise distance between the arithmetic centroids of seasonal home ranges (95\% adaptive kernel). The distance between the year-1 cool-season and warm-season home ranges was $1319 \mathrm{~m}(\mathrm{SE}=240)$. Distance between the warm-season and year-2 cool-season home ranges was $1342 \mathrm{~m}(\mathrm{SE}=108)$. These 2 estimates reflect seasonal migration distances between areas of concentrated use. Last, the distance between the 2 cool-season home ranges was $1323 \mathrm{~m}(\mathrm{SE}=250)$, which was used as another measure of site fidelity.

\section{Movement Metrics}

The daily use of elevation by deer showed 2 distinct patterns (Fig. 1). During cooler months ( February-May 2011 and November 2011-January 2012), the use of elevation was highly variable, showing patterns of repeated visits to higher elevations and then back to lower elevations (Fig. 1). Deer used elevations ranging from 2313 to $2436 \mathrm{~m}$ during $23 \mathrm{Feb}-$ ruary-31 May 2011 and 2341 to $2490 \mathrm{~m}$ during 1 November 2011-5 January 2012. In contrast, elevation use occurred over a much narrower range (2342-2416 m; Fig. 1) during the warmer months (June-October 2011).

During the warm season, female mule deer maintained crepuscular movement patterns; peak times of movement occurred around 06:00 and 18:00 (Fig. 2a). Movement distance 
A

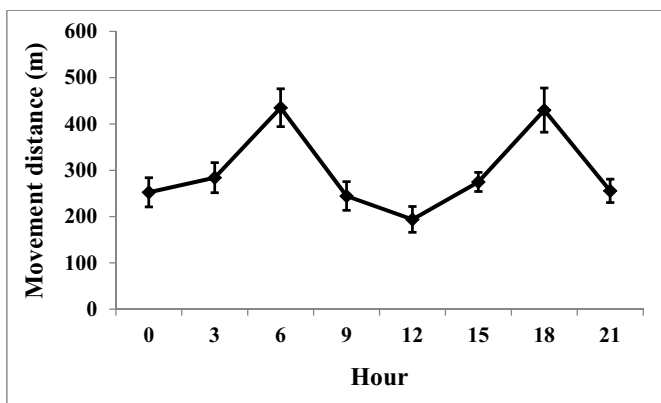

B

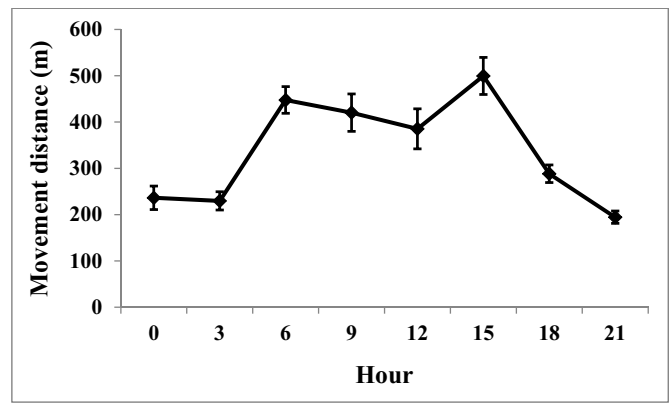

Fig. 2. Mean 3-h movement distance $(\mathrm{m})$ of female mule deer (Odocoileus hemionus) during the warm season (May-October; A) and cool season (November-April; B) in southern Wyoming and northern Colorado. Error bars represent \pm 2 standard errors.

was lowest during midday (12:00 h; Fig. 2a). Movement patterns changed during the cool season. Deer movement was greatest during daylight hours from 06:00 to 15:00 (Fig. 2b). Based on $95 \%$ confidence intervals, deer movement during the cool season was significantly lower during the night (18:00-03:00) than during the day.

Further partitioning the data by week allowed us to identify movement behavior related to the seasonal biology of female mule deer that influenced the broader temporalscale analysis by season. We observed 3 unique trends in the data. Firstly, the relative change in movement distance (i.e., change in magnitude of means by week) across weeks during the warm season was less variable compared to the cool season. Secondly, average distance traveled during each week of the cool season was more variable and intense in magnitude (i.e., rapid changes in movement from week to week), which may be related to environmental events (e.g., cold fronts, snowfall, etc.).
Lastly, during the warm season, we identified a one-month period in which movement distance was severely diminished. From midJune to mid-July, a period most likely encompassing parturition, distance traveled averaged 187-228 $\mathrm{m} \cdot$ day $^{-1}$ during the diurnal period and $174-283 \mathrm{~m} \cdot$ day $^{-1}$ during the nocturnal period (Fig. 3).

\section{Discussion}

Although many herds of mule deer migrate between higher-elevation summer range and lower-elevation winter range (Watkins et al. 2007, Cox et al. 2009, Monteith et al. 2011), it does not appear as though the sample of collared females in this study were migratory. Females were loyal to previously established seasonal home ranges, exhibiting little change in the spatial location of home ranges from season to season. Throughout the study, we observed rare events where mule deer made relatively long-distance movements (Fig. 3) to lower elevation followed by movement back to higher elevation (Fig. 1). We found that deer used lower elevations following a winter weather event such as snowfall or an approaching cold front (Appendix). After the winter weather subsided, deer returned to higher elevation until the next severe winter weather event (Fig. 1, Appendix). The changes in use of elevation may be attributed to the varying environmental (e.g., snow) conditions encountered by deer (Brown 1992) and likely were the result of deer searching for snow-free areas with cover and vegetation (Webb et al. 2013).

Despite many herds showing fidelity to seasonal ranges (Thomas and Irby 1990, Brown 1992, Matthews and Coggins 1997, Sawyer et al. 2005), deer in this herd showed both seasonal and annual fidelity to previously established home ranges. It appears that deer tracked during this study are year-round residents because they do not show any marked migration patterns except for changes in elevation use. The nonmigratory nature and high site fidelity of this population contrasts with many mule deer populations across the Intermountain West (e.g., Green River Basin, Wyoming; Sawyer et al. 2005), where most individuals exhibit seasonal migrations of 3.5-158 km (Thomas and Irby 1990, Brown 1992, Sawyer et al. 2005). Similar to other populations of nonmigratory deer $(\bar{x}=1.8 \mathrm{~km}$; Brown 1992), 


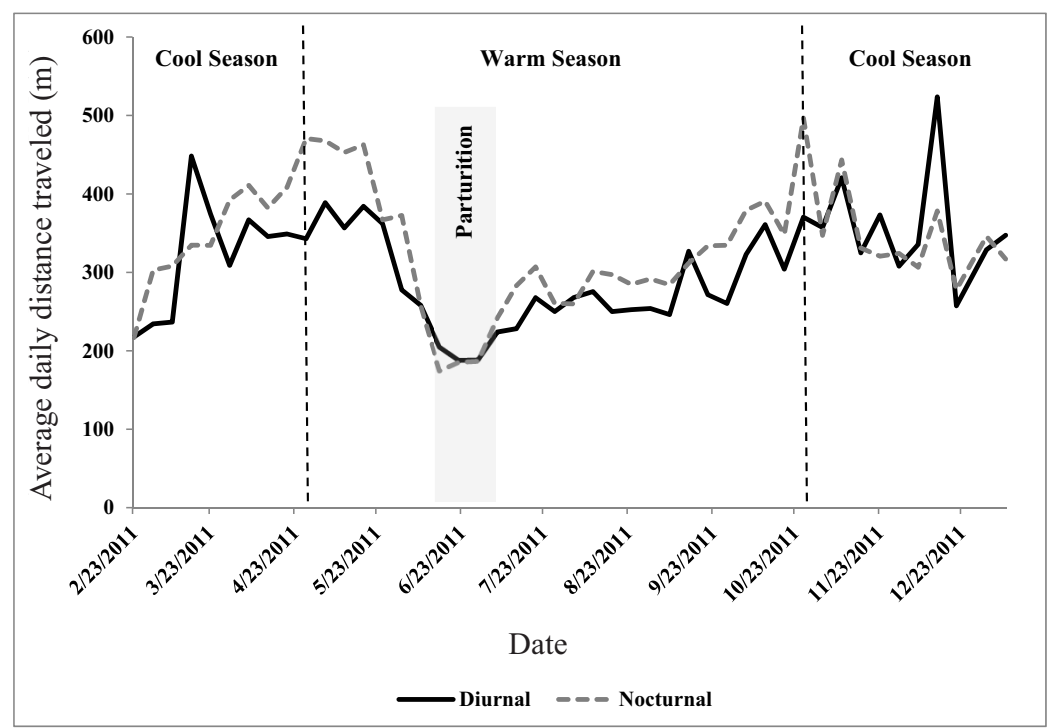

Fig. 3. Mean distance $(\mathrm{m})$ traveled by female mule deer (Odocoileus hemionus) during diurnal (solid line) and nocturnal (dashed line) periods in southern Wyoming and northern Colorado (23 February 2011-15 January 2012). Daily movement distance for diurnal and nocturnal periods was averaged within each respective week.

deer in this study moved an average of $1.3 \mathrm{~km}$ between seasonal ranges. In addition to strong site fidelity, mule deer in this nonmigratory population had a mean home-range size (2495 ha) similar to another nonmigratory population in Washington (2690-3780 ha, depending on estimator; Eberhardt et al. 1984). Nonmigratory deer exhibiting strong site fidelity likely were able to meet all of their resource needs within the defined spatial domain. The availability of forage, security cover, and thermal protection characterized the selection of resources by deer in this population (Webb et al. 2013). Having a well-established home range from season to season and year to year allows animals to move among resources and to escape danger because of their intimate knowledge of the surrounding area (Powell 2000).

Examining movement across seasons revealed patterns that may result from underlying environmental conditions that are linked to season (Webb et al. 2010b). During cooler months, deer maintained movement or activity patterns during daylight hours when ambient temperature was greatest (compared to nighttime when temperature was lowest). During warmer months, when midday and afternoon temperatures were greatest, deer exhibited a traditional crepuscular movement pattern (Eberhardt et al. 1984). These seasonal forms of movement may be attributed to general changes in environmental conditions that deer respond to in search of favorable thermal habitats (Randall et al. 2001, Webb et al. $2010 \mathrm{~b})$. The fact that deer also move seasonally between higher and lower elevations corroborates the finding that seasonal fluctuations in environmental conditions result in deer changing behavioral strategies (i.e., seasonal and diel activity patterns and shifts in distribution related to elevation) to improve thermal regulation, forage resources, protection, and fitness. Previous studies found that deer increased resting, and decreased feeding and movement, during periods of snowfall or in areas with deep snow. The adjusted behavior can result in decreased energy expenditure (Parker et al. 1984, Kufeld et al. 1988). Our results indicate that deer most likely are moving to areas with less snow to minimize energy expenditure and increase forage acquisition to maximize energy gain (Fig. 1, Appendix).

Seasonal movement behavior consists of finer-resolution behavior that occurs infrequently or over short temporal windows. For example, the aforementioned environmental events likely influenced movement behavior during the cool season. During the warm season, female mule deer give birth to young, and 
during this time, altered movement patterns have been used to estimate timing of parturition in ungulates (Vore and Schmidt 2001, Poole et al. 2007, Long et al. 2009, Dzialak et al. 2011). By examining movement at a finer resolution (i.e., week), we were able to approximate timing of parturition for this population of mule deer, which occurred from midJune to mid-July (Fig. 3). During this time, average movement distance during the day and night was much reduced compared to movement during all other times throughout the year. Also around the time of parturition, female mule deer made a trek to lower elevation $(\sim 2350 \mathrm{~m})$. Similar to previous studies (Vore and Schmidt 2001, Poole et al. 2007, Long et al. 2009, Dzialak et al. 2011), we were able to approximate timing of parturition by examining changes in movement behavior. Knowing the timing and location of parturition will help mitigate disturbance to females during this sensitive season.

These data offer ecological information on nonmigratory mule deer populations for the purpose of management and conservation and the potential development of game management unit boundaries and sizes. Game management units are common in the western United States, but little guidance has been given to resource managers on ways to define unit boundaries or sizes. As an example of how to use the types of data provided herein, we used computer programs developed by McCoy et al. (2005), Webb et al. (2007), and Webb et al. (2010a) to estimate potential GMU sizes for nonmigratory herds of mule deer. We estimated the area required to maintain $\sim 90 \%$ of the mule deer herd within a defined GMU based on the average home-range size of 2495 ha (converted to a radius in meters [2818.1]) and a seasonal movement distance of $1342 \mathrm{~m}$. Simulations revealed that an area $>7500 \mathrm{~km}^{2}$ would be required to manage $\sim 90 \%$ of the mule deer herd (from a nonmigratory population) on an annual basis. When mule deer are nonmigratory, it may be feasible to manage an entire herd or population with one or only a few game management units. However, when mule deer undertake migratory movements, the size of the GMU will increase dramatically or require cooperation among multiple units.

Based on daily and seasonal movement patterns, strategies can be developed to minimize disturbance to deer during periods of peak activity or during sensitive seasons (e.g., winter and parturition). Understanding the daily and seasonal patterns of movement and space use would allow the development of more precise best management practices that could minimize disturbance to deer while allowing for development or recreation. Understanding spatial patterns could allow managers to focus attention on areas preferred by deer and thereby conserve or manage habitat to meet the needs of deer during critical seasons. Because females in this herd are nonmigratory and have high site fidelity, it is unknown whether development will displace females. When deer are tied strongly to previously established ranges, understanding the components and juxtaposition of resources selected offers a critical piece of information that can be extrapolated to other populations. For example, deer preferentially selected areas in close proximity to thermal and security cover (e.g., rugged terrain and shrubland) as well as forage resources (i.e., alfalfa fields; Webb et al. 2013). Therefore, coupling temporal behavior patterns with spatially explicit data (e.g., predicted maps of occurrence based on resource selection patterns) offers managers the most complete set of information to manage resident deer populations in the face of expanding energy development. Protecting important resources during activity periods and critical seasons is important because most ungulate species show varying selection for specific landscape features during day and night (Dzialak et al. 2011) and during critical seasons such as calving (Dzialak et al. 2011, Wilson et al. 2012) and winter (Harju et al. 2011, Webb et al. 2013). By understanding basic behavior and selection patterns of animals prior to any land development, models can be constructed to predict the amount of area and habitat that will be affected by development. This development could result in displacement of animals to other areas, should other areas even exist in the same composition and juxtaposition of landscape features (Wilson et al. 2012).

\section{ACKNOWLEDGMENTS}

We thank Ridgeline Energy, LLC, for funding; Tetra Tech EC, Inc., for logistical support; M. Griswold, A. Miller, J. Voorhees, K. Harper, S. Gamo, and R. Guenzel for project 
support and assistance; and B.R. McMillan and several anonymous reviewers for improving early drafts of this manuscript.

\section{Literature Cited}

Ager, A.A., B.K. Johnson, J.W. Kern, And J.G. Kie. 2003. Daily and seasonal movements and habitat use by female Rocky Mountain elk and mule deer. Journal of Mammalogy 84:1076-1088.

Audigé, L., P.R. Wilson, AND R.S. Morris. 1998. A body condition score system and its use for farmed red deer hinds. New Zealand Journal of Agricultural Research 41:545-553.

Beier, P., AND D.R. McCullough. 1990. Factors influencing white-tailed deer activity patterns and habitat use. Wildlife Monographs 109:1-51.

Brown, C.G. 1992. Movement and migration patterns of mule deer in southeastern Idaho. Journal of Wildlife Management 56:246-253.

Cook, R.C., J.G. Cook, T.R. Stephenson, W.L. Myers, S.M. McCorquodale, D.J. Vales, L.L. Irwin, P.B. Hall, R.D. Spencer, S.L. Murphie, et AL. 2010. Revisions of rump fat and body scoring indices for deer, elk, and moose. Journal of Wildlife Management 74:880-896.

Cox, M., D.W. Lutz, T. Wasley, M. Fleming, B.B. Compton, T.W. Keegan, D. Stroud, S. Kilpatrick, K. Gray, L. Carpenter, ET aL. 2009. Habitat guidelines for mule deer: Intermountain West region. Mule Deer Working Group, Western Association of Fish and Wildlife Agencies, Cheyenne, WY.

Dzialak, M.R., S.M. Harju, R.G. Osborn, J.J. Wondzell, L.D. Hayden-Wing, J.B. Winstead, and S.L. WebB. 2011. Prioritizing conservation of ungulate calving resources in multiple-use landscapes. PLOS ONE 6(1): e14597, http://dx.doi.org/10.1371/journal.pone .0014597

Eberhardt, L.E., E.E. Hanson, and L.L. Cadwell. 1984. Movement and activity patterns of mule deer in the sagebrush-steppe region. Journal of Mammalogy 65:404-409.

Fieberg, J., and C.O. Kochanny. 2005. Quantifying home-range overlap: the importance of the utilization distribution. Journal of Wildlife Management 69:1346-1359.

Fryxell, J.M., and A.R.E. Sinclair. 1988. Causes and consequences of migration by large herbivores. Trends in Ecology and Evolution 3:237-241.

Gerhart, K.L., R.G. White, R.D. Cameron, and D.E. RusseLL. 1996. Estimating fat content of caribou from body condition scores. Journal of Wildlife Management 60:713-718.

Harju, S.M., M.R. Dzialak, R.G. Osborn, L.D. HaydenWing, AND J.B. WinsteAD. 2011. Conservation planning using resource selection models: altered selection in the presence of human activity changes spatial prediction of resource use. Animal Conservation 14:502-511.

Kufeld, R.C., D.C. Bowden, and D.L. Schrupp. 1988. Habitat selection and activity patterns of female mule deer in the Front Range, Colorado. Journal of Range Management 41:515-522.

Long, R.A., J.G. Kie, R.T. Bowyer, and M.A. Hurley. 2009. Resource selection and movements by female mule deer Odocoileus hemionus: effects of reproductive stage. Wildlife Biology 15:288-298.

Lutz, D.W., J.R. Heffelfinger, S.A. Tessmann, R.S. Gamo, AND S. Siegel. 2011. Energy development guidelines for mule deer. Mule Deer Working Group, Western Association of Fish and Wildlife Agencies, Wyoming.

Matthews, P.E., And V.L. Coggins. 1997. Movements and mortality of mule deer in the Wallowa Mountains. Pages 78-88 in J.C. deVos Jr., editor, Proceedings of the 1997 Deer/Elk Workshop. Arizona Game and Fish Department, Rio Rico, AZ.

McCoy, J.E., D.G. HewitT, and F.C. BRyant. 2005. Dispersal by yearling male white-tailed deer and implications for management. Journal of Wildlife Management 69:366-376.

Millspaugh, J.J., R.A. Gitzen, B.J. Kernohan, M.A. LaRSON, AND C.L. Clay. 2004. Comparability of three analytical techniques to assess joint space use. Wildlife Society Bulletin 32:148-157.

Monteith, K.L., V.C. Bleich, T.R. Stephenson, B.M. Pierce, M.M. Conner, R.W. Klaver, and R.T. BowYER. 2011. Timing of seasonal migration in mule deer: effects of climate, plant phenology, and lifehistory characteristics. Ecosphere 2(4): art47, http://dx .doi.org/10.1890/ES10-00096.1

Parker, K.L., C.T. Robbins, and T.A. Hanley. 1984. Energy expenditures for locomotion by mule deer and elk. Journal of Wildlife Management 48:474-488.

Poole, K.G., R. Serrouya, and K. Stuart-Smith. 2007. Moose calving strategies in interior montane ecosystems. Journal of Mammalogy 88:139-150.

Powell, R.A. 2000. Animal home ranges and territories and home range estimators. Pages $65-110$ in L. Boitani and T.K. Fuller, editors, Research techniques in animal ecology: controversies and consequences. Columbia University Press, New York, NY.

Randall, D., W. Burggren, and K. French. 2001. Eckert animal physiology: mechanisms and adaptations. 5 th edition. W.H. Freeman, New York, NY.

RinEY, T. 1960. A field technique for assessing physical condition of some ungulates. Journal of Wildlife Management 24:92-94.

Robinette, W.L., D.A. Jones, G. Rogers, and J.S. GashWILER. 1957. Notes on tooth development and wear for Rocky Mountain mule deer. Journal of Wildlife Management 21:134-153.

Rodgers, A.R., A.P. Carr, L. Smith, and J.G. Kie. 2005. HRT: home range tools for ArcGIS. Ontario Ministry of Natural Resources, Centre for Northern Forest Ecosystem Research, Thunder Bay, Canada.

SaWyer, H., F. Lindzey, and D. MCWhirter. 2005. Mule deer and pronghorn migration in western Wyoming. Wildlife Society Bulletin 33:1266-1273.

Sikes, R.S., W.L. Gannon, and the Animal Care and Use Committee of the AMERICAN Society of MamMALOGISTS. 2011. Guidelines of the American Society of Mammalogists for the use of wild mammals in research. Journal of Mammalogy 92:235-253.

Thomas, R.R., and L.R. Irby. 1990. Habitat use and movement patterns by migrating mule deer in southeastern Idaho. Northwest Science 64:19-27.

Vore, J.M., AND E.M. SCHMIDT. 2001. Movements of female elk during the calving season in northwest Montana. Wildlife Society Bulletin 29:720-725.

Watkins, B.E., C.J. Bishop, E.J. Bergman, B. Hale, B.F. Wakeling, A. Bronson, L.H. Carpenter, and D.W. 
LuTZ. 2007. Habitat guidelines for mule deer: Colorado Plateau shrubland and forest ecoregion. Mule Deer Working Group, Western Association of Fish and Wildlife Agencies, Cheyenne, WY.

Webb, S.L., S. Demarais, and D.G. Hewitt. 2010a. Size of home ranges and movements determine size and configuration of management units and potential spread of disease in white-tailed deer (Odocoileus virginianus). Southwestern Naturalist 55:488-492.

Webb, S.L., M.R. Dzialak, K.L. Kosciuch, and J.B. WinSTEAD. 2013. Winter resource selection by mule deer on the Wyoming-Colorado border prior to wind energy development. Rangeland Ecology and Management 66:419-427.

Webb, S.L., K.L. Gee, B.K. Strickland, S. Demarais, and R.W. DeYoung. 2010b. Measuring fine-scale white-tailed deer movements and environmental influences using GPS collars. International Journal of Ecology: Article ID 459610, http://dx.doi.org/10 $.1155 / 2010 / 459610$

WebB, S.L., D.G. Hewitt, and M.W. Hellickson. 2007. Scale of management for mature male white-tailed deer as influenced by home range and movements. Journal of Wildlife Management 71:1507-1512.

Webb, S.L., J.S. Lewis, D.G. HewitT, M.W. Hellickson, and F.C. BRYant. 2008. Assessing the helicopter and net gun as a capture technique for white-tailed deer. Journal of Wildlife Management 72:310-314.

Wilson, R.R., A.K. Prichard, L.S. Parrett, B.T. Person, G.M. Carroll, M.A. Smith, C.L. Rea, and D.A. YOKEL. 2012. Summer resource selection and identification of important habitat prior to industrial development for the Texhekpuk caribou herd in northern Alaska. PLoS ONE 7(11):e48697, http://dx.doi .org/10.1371/journal.pone.0048697

Worton, B.J. 1989. Kernel methods for estimating the utilization distribution in home-range studies. Ecology 70:164-168.

Received 14 May 2012 Accepted 30 May 2013

APPENDIX. Post hoc extraction of weather data before (3 days before relocation) and during (day of relocation) periods that corresponded with rapid relocation to lower elevations by female mule deer (Odocoileus hemionus) from 23 February 2011 to 15 January 2012 on the Wyoming-Colorado border. Weather was collected at the Laramie FAA Regional Airport in Laramie, Wyoming, and obtained from the High Plains Climate Center at the University of Nebraska-Lincoln.

\begin{tabular}{|c|c|c|c|c|}
\hline Date & Period & Temperature $\left({ }^{\circ} \mathrm{C}\right)^{\mathrm{a}}$ & Precipitation $(\mathrm{cm})^{\mathrm{b}}$ & Snowfall $(\mathrm{cm})^{\mathrm{b}}$ \\
\hline 6-8 March 2011 & Before & -7.8 & 0.025 & 0 \\
\hline 9 March 2011 & During & -7.2 & 0 & 0 \\
\hline 29 April-1 May 2011 & Before & -9.4 & 0.076 & 0 \\
\hline 2 May 2011 & During & -8.9 & 0 & 0 \\
\hline 11-13 May 2011 & Before & -1.1 & 1.016 & 0 \\
\hline 14 May 2011 & During & -3.3 & 0 & 0 \\
\hline 30 October-1 November 2011 & Before & -1.3 & 0.483 & 3.124 \\
\hline 2 November 2011 & During & -25.0 & 0.025 & 6.071 \\
\hline 29 November-1 December 2011 & Before & -10.7 & 0.203 & 2.540 \\
\hline 2 December 2011 & During & -21.7 & 0.051 & 0.838 \\
\hline 11-13 December 2011 & Before & -16.8 & 0 & 0 \\
\hline 14 December 2011 & During & -16.7 & 0 & 0 \\
\hline 5-7 January 2012 & Before & -7.2 & 0 & 0 \\
\hline 8 January & During & -16.1 & 0 & 0 \\
\hline
\end{tabular}

aTemperature was the 3-day average prior to the relocation event.

bPrecipitation and snowfall were the 3-day totals prior to the relocation event. 